IZA DP No. 9709

Profiling the US Sick Leave Landscape

Philip Susser

Nicolas R. Ziebarth

February 2016

Forschungsinstitut zur Zukunft der Arbeit Institute for the Study of Labor 


\title{
Profiling the US Sick Leave Landscape
}

\author{
Philip Susser \\ Cornell University \\ Nicolas R. Ziebarth \\ Cornell University \\ and IZA
}
Discussion Paper No. 9709
February 2016

\author{
IZA \\ P.O. Box 7240 \\ 53072 Bonn \\ Germany \\ Phone: +49-228-3894-0 \\ Fax: +49-228-3894-180 \\ E-mail: iza@iza.org
}

Any opinions expressed here are those of the author(s) and not those of IZA. Research published in this series may include views on policy, but the institute itself takes no institutional policy positions. The IZA research network is committed to the IZA Guiding Principles of Research Integrity.

The Institute for the Study of Labor (IZA) in Bonn is a local and virtual international research center and a place of communication between science, politics and business. IZA is an independent nonprofit organization supported by Deutsche Post Foundation. The center is associated with the University of Bonn and offers a stimulating research environment through its international network, workshops and conferences, data service, project support, research visits and doctoral program. IZA engages in (i) original and internationally competitive research in all fields of labor economics, (ii) development of policy concepts, and (iii) dissemination of research results and concepts to the interested public.

IZA Discussion Papers often represent preliminary work and are circulated to encourage discussion. Citation of such a paper should account for its provisional character. A revised version may be available directly from the author. 
IZA Discussion Paper No. 9709

February 2016

\section{ABSTRACT}

\section{Profiling the US Sick Leave Landscape ${ }^{*}$}

This paper profiles the sick leave landscape in the US - the only industrialized country without universal access to paid sick leave or other forms of paid leave. We exploit the 2011 Leave Supplement of the American Time Use Survey (ATUS), a representative and comprehensive database on sick leave in the US. The two binary outcome variables measure (i) access to paid sick leave and (ii) suppressed sick leave ("presenteeism"). Thirty-five percent of US full-time employees lack access to paid sick leave. Low-income employees, service sector employees, and those in poor health have the lowest coverage rates. We estimate that, each week, up to three million US employees suppress their need for sick leave and engage in presenteeism behavior. These are primarily women with children and low-wage sector jobs.

JEL Classification: I12, I13, I18, J22, J28, J32

Keywords: $\quad$ sick leave, paid leave, medical leave, unpaid leave, low-income employees, gender inequality, presenteeism, US

Corresponding author:

Nicolas R. Ziebarth

Cornell University

Department of Policy Analysis and Management (PAM)

106 Martha Van Rensselaer Hall

Ithaca, NY 14850

USA

E-mail: nrz2@cornell.edu

\footnotetext{
* Short and revised version forthcoming in Health Services Research. We take responsibility for all remaining errors in and shortcomings of the article. Generous support from the W.E. Upjohn Institute for Employment Research (2015 Early Career Research Award), the Cornell Population Center (Rapid Response Grant), the Cornell Institute for the Social Sciences (Small Grant), and the Mario Einaudi Center for International Studies (Seed Grant) is gratefully acknowledged. The research reported in this paper is not the result of a for-pay consulting relationship. Cornell does not have a financial interest in the topic of the paper which might constitute a conflict of interest.
} 


\section{Introduction}

"Send me a bill that gives every worker in America the opportunity to earn seven days of paid sick leave."

Barack Obama in his State of the Union Address on January 20, 2015

"I think the Republicans would be smart to get behind it."

Bill O'Reilly in The O'Reilly Factor (Fox News) on January 21, 2015

Paid sick leave was among the first social insurance pillars worldwide, being a key component of the first statutory health insurance legislation in Germany. Germany's Sickness Insurance Law of 1883 included 13 weeks of paid sick leave and coverage for medical bills. Because of the limited availability of expensive medical treatments in the $19^{\text {th }}$ century, the costs for paid sick leave originally made up more than half of all program costs (Busse and Riesberg 2004). Other European countries followed. Today, every European country provides universal access to paid sick leave, with varying degrees of generosity (Heyman et al. 2010; Ziebarth, 2013; Ziebarth and Karlsson 2010, 2014).

Although United States Workers' Compensation was gradually introduced after World War I at the state level, several attempts to implement universal health insurance and sick leave coverage failed. Consequentially, the US remains the only industrialized country without universal health insurance and sick leave coverage (Heyman et al. 2010; Schliwen et al. 2011). However, underscored by the epigraph, support for US paid sick leave has grown substantially in the last decade (Lovell, 2003; Levin-Epstein, 2005; Public Welfare Foundation, 2008; Ben-Ishai, 2014). The 2008 National Paid Sick Days Study (NPSDS) found that a large majority (>80\%) of respondents support paid sick leave mandates and believe that paid sick leave is a "basic labor standard." 
In recent years, several sick leave mandates were passed at the city level in San Francisco, Washington D.C., Seattle, Portland, and New York City among other cities. In 2012, Connecticut was the first state to introduce a sick leave scheme for service sector workers in non-small businesses (Ahn and Yelowitz 2015). California, Massachusetts and Oregon followed with more comprehensive mandates in 2015 and 2016. Federal legislation is also being considered. Reintroduced to Congress in March 2013, the Healthy Families Act proposes the introduction of a federal paid sick leave program. The bill would require non-small employers to provide full-time employees with one hour of paid sick leave for every thirty hours worked, for up to seven days per employee and year.

Whereas paid maternity leave may largely be considered a social insurance program to fight inequality and improve the well-being of families (Han et al. 2009; Rossin-Slater et al. 2013, Gault et al. 2014), there is an additional economic argument for sick leave mandates: The cause of sickness is largely unobservable, which can lead to information asymmetries between employees and employers. Negative externalities could be reduced by inducing contagious employees to call in sick and, thus, not spread their disease to coworkers and customers. Evaluating the effects of recently implement US sick leave mandates, Pichler and Ziebarth (2015) provide evidence that the rate of influenza-like diseases decreased by about $5 \%$ at the population level in subsequent months.

Given low vaccination rates in both the United States (40\%) and the European Union (10$30 \%)$, workplace presenteeism is one important channel through which contagious diseases like influenza spread (Blank et al. 2009, CDC 2014a). What's more, the availability of over-the-counter 
(OTC) drugs that suppress illness symptoms, but fail to curb contagiousness, reinforces the spread of diseases under presenteeism (Earn et al. 2014). Humans are contagious for five to seven days after the first indication of flu-like symptoms, so there is a relatively large window of time to spread illness (CDC 2014b). Worldwide, seasonal influenza epidemics alone lead to 3 to 5 million severe illnesses and an estimated 250,000 to 500,000 deaths. In the US, the annual death toll associated with the flu ranges from 3,000 to 49,000 individuals (WHO 2014, CDC 2014b). In addition to public health hazards, other possible negative consequences of workplace presenteeism include lower work productivity, a worsened workplace environment, and lower job satisfaction.

On the other hand, opponents of sick leave mandates point to the fact that mandated sick leave would encourage shirking behavior and reduce labor supply. Moreover, forcing employers to provide sick pay via mandates or new taxes would increase labor costs and thus dampen job creation and hurt employment. A final argument against government-mandated sick leave states that, when coverage is optimal, the private market would ensure that employers voluntarily provide such benefits.

This paper empirically profiles the sick leave landscape in the US, exploiting the representative 2011 Leave Supplement of the American Time Use Survey (ATUS). To our knowledge, this supplement has not been systematically analyzed in a peer-reviewed publication.

Fifty-five percent of American employees have access to paid sick leave. There are large differences across industries and type of work, and there are large differences by socio- 
demographics. Sick leave coverage rates are significantly below $40 \%$ for part-time employees, low-income employees, very young and very old employees, as well as employees in fair or poor health.

When analyzing the need for paid leave, one finds: In a given week of the year, $4.8 \%$ of employees actually took sick leave due to own sickness, and $1.6 \%$ took sick leave due to a relative's sickness. Another $1.3 \%$ of employees decided to not take sick leave but instead reschedule their work hours. Finally, $2.1 \%$ of US employees would have needed sick leave but did not take it. These representative numbers imply that about two percent of the US workforceor up to three million Americans-go to work sick every week. When analyzing who these people are, a clear picture emerges: low-income, female employees with children and those who are in fair or poor health are relatively more likely to engage in presenteeism behavior.

\section{Database and Empirical Analysis}

\subsection{ATUS Leave Supplement 2011}

The database utilized in this paper is the American Time Use Survey (ATUS), an annually conducted survey by the Bureau of Labor Statistics. The ATUS is a nationally representative crosssectional dataset with approximately 14,000 participating households every year, equally distributed over all months of the year (BLS 2014). The ATUS sample is drawn from the Current Population Survey (CPS). Following the completion of CPS interview procedures, respondents become eligible for the ATUS; they are contacted by letter and are interviewed through 
Computer-Assisted Telephone Interviewing (CATI). As reflected by its name, the ATUS focuses its questions on American's time usage (US Department of Labor 2015).

In 2011, a special "Leave Module" was included in the ATUS survey. We merge this Leave Module information with the socio-demographic information from the regular interviews. Because only employed respondents were eligible for the Leave Module, our final sample consists of 6,354 respondents with no "missings" on their relevant variables. ${ }^{1}$ We routinely use sample weights from the ATUS Leave Module in our empirical analysis.

\subsection{Access to Paid and Unpaid (Sick) Leave}

Access to General Leave Coverage. The first set of outcome variables measures access to paid and unpaid general leave opportunities among US employees. The descriptive statistic for the different leave measures is in Table A1 in the Appendix. Sixty-one percent of all American employees have access to some form of paid leave. When looking at access to unpaid leave, the share of workers increases to $77 \%$.

Table A2 in the Appendix cross-tabulates general access to paid and unpaid leave from work. About half of all US employees, $47 \%$, are able to take both paid and unpaid leave. Approximately $30 \%$ have access to unpaid leave, without an option to take paid leave. Finally, $8.5 \%$ of all employees do not have access to either paid or unpaid leave.

\footnotetext{
${ }^{1}$ We leave the sample as unrestricted as possible. The first filter question was answered by 6,602 respondents and had 71 missings. In order to keep the sample size stable across models to allow for clean comparisons, we drop an additional $248(3.8 \%)$ respondents with missings on one of the other covariates.
} 
Access to Specific Types of Paid Leave. Table A1 also differentiates by different types of leave.

As mentioned, the first ATUS Leave Supplement question asks employees whether they receive paid leave-in general-on their main job. Those $61 \%$ who answer 'yes' are then asked whether they could take paid leave for specific reasons, among them 'own sickness.' Nearly everyone with access to general paid leave also has access to paid sick leave-in fact more than $90 \%$. Paid sick leave is clearly the most common type of paid leave offered by US employers. Overall, $55 \%$ of all US employees are offered paid sick leave according to the 2011 ATUS. Other surveys and reports indicate similar shares (Lovell 2003; Boots et al. 2009; CEA 2014; Gault et al. 2014). For example, the National Compensation Survey, which surveys employers, reports that $61 \%$ of US employees would be covered by paid sick leave in 2012 (up from 50\% in 1992/1993) (Van Giezen, 2013). The empirical findings for the two variables Access to Paid Leave and Access to Paid Sick Leave are nearly perfectly correlated; henceforth, we focus on Access to Paid Sick Leave.

However, Table A1 in the Appendix provides interesting insights into the other types of paid leave. Less than half of all employees, $44 \%$, can take paid leave for a sick family member. ${ }^{2}$ Paid leave for eldercare is offered to $27 \%$ and $40 \%$ can take paid leave when their child is born.

Consolidated Leave Plans. In the US, it is increasingly common that employers offer a single "convertible" form of paid leave that can either be used as paid vacation, paid maternity leave, or paid sick leave. Such plans are sometimes called "Consolidated Leave Plans" or "PTO Banks" (Lindemann and Miller, 2012). Because "Consolidated Leave Plans" do not represent sick pay

\footnotetext{
${ }^{2} 99.3 \%$ of those who report that they can take paid leave for a sick family member also report that they can take paid leave for their own illness.
} 
schemes in the narrow sense ${ }^{3}$, Access to Paid Sick Leave overestimates the true rate of (separate) sick leave coverage if employees with such plans claim that they can take paid sick leave. The Leave Supplement explicitly asks respondents whether their employer would offer (a) a PTO plan and/or (b) paid sick leave separately. Respondents who answer positive on the former question, negative on the latter, and still claim that they can take paid leave when sick, represent $15 \%$ of all employees. Thus, only around $40 \%$ have sick pay coverage and also claim that their employer offers a separate sick leave plan. ${ }^{4}$

Sick Leave Coverage Rates by Socio-Demographics. All stratifying variables in Figures 1 and A1 below are based on self-reports. The female, age, and number of children variables are generated accordingly. Figure A1d is based on the standard five-categorical self-assessed health question (Ziebarth, 2010), where we collapse the lowest two categories "fair" and "poor" as well as the highest three categories "excellent," "very good", "good." The hourly wage variable is generated from ATUS self-reports about wage; by dividing the weekly salary by the indicated

\footnotetext{
3 "Consolidated" paid leave appears to be superior to paid leave under separate categories. The BLS reports that the average PTO bank has 20 days of total paid leave after five years of service with the employer. Is has been argued that employers offer PTO plans to reduce the overall number of paid leave days (Lindemann and Miller, 2012). In addition, PTO plans may not reduce contagious presenteeism in an optimal way because employees are reluctant to use their paid vacation for sickness. Note that employees are always free to use their paid vacation as personal sick days or for any other reason.

${ }^{4} 89$ respondents deny that they have separate sick leave plans, indicate to have a PTO plan, and also deny that they can take paid leave when sick. While all these statement could be simultaneously true, we suspect small reporting errors among those 89 respondents and code zero on Access to Paid Sick Leave. The findings are robust when recoding these 89 respondents.
} 
typical weekly hours worked, we were able to derive the hourly wage. ${ }^{5}$ All descriptives are in Table $\mathrm{A} 1$ in the Appendix.

Figure A1 shows the share of US employees with Access to Paid Sick Leave stratified by (a) female vs. male, (b) kids vs. no kids, (c) full-time vs. part-time work, and (d) at least good health vs. fair or poor health. This figure shows mean comparisons in bar diagrams, plotted with $95 \%$ confidence intervals.

In this raw comparison, one does not find statistical differences by gender or kids. But, the following can be concluded: First, the probability of having paid sick leave increases by $45 \mathrm{ppt}$ when employees work full-time (65\% vs. $20 \%$ ). Yet, $35 \%$ of full-time employees cannot take paid sick leave. Second, employees with self-reported fair or poor health are $13 p p t(47 \%$ vs $60 \%)$ less likely to have access to paid sick leave, which is statistically significant. Note that all statistical relationships reported in this paper are pure correlations and do not represent causal relationships. For example, it could be that a lack of sick leave coverage leads to bad health or that unhealthy employees sort into jobs with low coverage rates. The bivariate correlation observed could also be driven by third observable or unobservable variables. We will correct for observables in multivariate regressions below.

\section{[Insert Figure 1 about here]}

\footnotetext{
${ }^{5}$ Obviously the latter variable contains measurement errors. But, we decided against further manipulation. As seen in the Appendix, due to a long right tail, the mean is very high at $\$ 41.45$. The median is just $\$ 17.85$. The findings are robust to excluding those 114 respondents with an hourly wage of more than $\$ 200$.
} 
Figure 1 shows the probability of having paid sick leave coverage by (i) hourly wage, (ii) age, (iii) number of children in the household, and (iv) level of pain on a scale from 0 to 10 . First, low wage earners have minimal access to paid sick leave in the US. Coverage rates are near $20 \%$ at the minimum wage level and then increase to $60 \%$ at a wage of $\$ 18$ per hour. Coverage rates continue to directly correlate with wages up to an hourly wage of approximately $\$ 30$. Coverage then plateaus at about $80 \%$.

Second, the probability of having access to paid sick leave increases strongly with age. While employees under the age of 20 have coverage rates of less than $20 \%$, employees 30 to 60 years old have coverage rates at around $60 \%$. Beyond the age of 60 , coverage rates begin to decrease again.

Third, Figure 1 also shows that coverage linearly decreases from a baseline level of $60 \%$ (to $40 \%$ ) when more than two kids under the age of 18 are present in the household.

Finally, access to paid sick leave decreases significantly with the level of self-reported pain. Employees who report a physical pain level of 9 or 10 (on a scale from 0 to 10) have coverage rates at around $40 \%$. Coverage rates for self-reported pain levels below 3 are twice as high.

Paid Sick Leave by Industry. Table A3 reports paid sick leave coverage rates by industry and reveals a clear pattern. The industries with the highest coverage rates are public administration (89\%), finance (78\%), and transportation (69\%). The industries with the lowest coverage rates are construction (34\%), service sector (36\%), agriculture (29\%), as well as leisure and hospitality 
(19\%). Consequently, low coverage rates are particularly prevalent in the service sector with high potential for the spread of contagious diseases due to presenteeism.

Nonparametrics Summary. Whereas forty-five percent of all US employees lack paid sick leave coverage, $35 \%$ of full-time employees lack coverage. Coverage rates are particularly low among (i) low-income employees who make less than $\$ 20$ an hour, (ii) those in pain and bad health, and (iii) those who work in the hospitality and leisure industry. Coverage rates are relatively high-although far from universal-amongst middle-aged full time employees. Workers in finance and public administration have coverage rates of 80 and $90 \%$, respectively.

Multivariate Regression Results. Next, we estimate the determinants of having paid sick leave coverage using a multivariate parametric regression framework. While the nonparametric results compare coverage rates by one single stratifying variable, the multivariate framework allows for multiple access determinants to be controlled for simultaneously. For example, using a multivariate framework, we can answer questions such as: "Are low-wage employees less likely to have access to paid sick leave, controlling for gender, age, number of children, health, full-time work, and industry?"

\section{[Insert Table 1 about here]}

Table 1 shows the regression results and provides an answer to this question and similar questions. The first three columns estimate models using Access to Paid Sick Leave as the outcome variable. Each column corresponds with a regression model. The models only differ by 
the sets of covariates included. A stepwise inclusion of control variables allows us to elucidate the role of socio-demographics as they are added to the model.

Table 1 confirms our descriptive findings and contributes additional insights. As already shown in Figure 1b, we find that coverage rates significantly increase with age in a non-linear manner. We also find that full-time or part-time work status, the wage, and the industry are significantly related to coverage probabilities.

First, controlling for all other socio-demographics, full-time work increases coverage probabilities by a highly significant and large 35ppt (cf. Figure A1c for a nonparametric equivalent).

Second, an hourly wage increase of $\$ 1$ is associated with a $2.7 \mathrm{ppt}$ higher probability of having paid sick leave, relative to a baseline level of $55 \%$ (see also Figure 1 a).

Third, a poor health status dramatically reduces the likelihood of being able to take paid leave while sick, even when controlling for job type and other socio-demographics. Relative to employees with "satisfactory" health, being in fair or poor health is associated with a highly significant 11ppt lower probability to be able to take paid sick leave.

Fourth, the multivariate regression results of the industry analysis also corroborate the descriptive nonparametric evidence. Note that the reference group in the regression models is agriculture with one of the lowest coverage rates (29\%). Non-significant coefficients in this particular regression then reflect low coverage rates. As seen, controlling for factors such as 
salary or the health status, coverage rates are a highly significant 29ppt, 38ppt, and 46ppt higher in transportation, finance, and public administration, respectively (see Table 1, column 3).

\subsection{Utilization of Sick Leave, Presenteeism, and Avoidance Strategies}

Having analyzed coverage rates across industries, job characteristics, and sociodemographics, we next analyze actual sick leave utilization and suppressed utilization. The Appendix provides summary statistics for four important variables in this context.

Need for Sick Leave. First of all, $4.8 \%$ of all interviewed employees took personal sick leave in the week prior to the interview. An additional $1.6 \%$ took leave for a sick family member. In addition, $1.3 \%$ rescheduled their work hours or work location due to own or a relative's sickness. Another $2.1 \%$ indicated that they would have needed to take sick leave, but did not or could not take it. When summing up these percentages, one obtains a total "demand" for personal and family-related sick leave of $9.8 \%$. What's more, leave was only effectively taken in $6.4 \%$ of all cases while the rest rescheduled work or found other avoidance strategies, e.g., went to work sick ("presenteeism").

The presenteeism rate in our data is $2.1 \%$. Relative to an estimated 130 to 140 million employees between 2011 and today (BLS 2015), this representative rate translates to between 2.7 and 3 million US employees going to work sick (or not being able to take care of their sick child) in a given week of the year. That is not to say a universal coverage system would completely eliminate the prevalence of people who go to work sick. Even under a $100 \%$ universal coverage rate like in Europe, a significant share of employees decide not to take sick leave, e.g., out of fear 
of losing their jobs, and engage in presenteeism behavior (Ziebarth and Karlsson 2010, 2014;

Pichler and Ziebarth, 2015). ${ }^{6}$

\section{[Insert Table 2 about here]}

Reasons for Suppressing Sick Leave. Tables 2 analyzes the underlying reasons why employees decide to abstain from taking sick leave. Note that all these numbers condition on those who needed but did not take sick leave in the week prior to the interview.

The upper panel of Table 2 shows that of those who needed sick leave but did not take it, $6.8 \%$ wanted to save their leave, $4.6 \%$ were denied leave, and $27.2 \%$ claimed that they could not afford the loss of income in taking unpaid leave. Another $1.7 \%$ indicated that they would not have enough leave. All these reasons, making up 40.27\%, could be subsumed under "not having comprehensive paid sick leave access or coverage." One could thus hypothesize that the implementation of comprehensive access to paid sick leave could reduce the presenteeism rate of two percent of the US workforce significantly, e.g., by roughly one million presenteeism cases per week.

By contrast, the lower panel lists reasons that could be subsumed under "job consequences and other." Whereas $11.0 \%$ directly indicate that they feared negative job consequences when

\footnotetext{
${ }^{6}$ As a comparison, under Germany's generous mandated sick leave scheme-with up to six weeks of paid sick leave without wage cuts-, on a given workday, $4 \%$ of the workforce is on sick leave. During the flu season, each day about $1.5 \%$ are on sick leave due to colds and flus (Techniker Krankenkasse, 2015). About half the workforce report zero sick days per year but, on average, employees take 15 days of paid sick leave (Ziebarth and Karlsson 2010, 2014). The majority of sick days are due to musculoskeletal diseases-back pain-(20\%), mental diseases (18\%), and respiratory diseases (13\%) which also include influenza (Techniker Krankenkasse, 2015).
} 
taking sick leave, $20.4 \%$ simply indicated "too much work" as a reason for working sick. "Other reasons" make up $28.4 \%$.

Suppressed Need by Socio-Demographics. Next, we characterize the group of employees that needed leave but did not or could not take it. Figure A2 stratifies the rate of suppressed leave by certain socio-demographics such as (a) gender, (b) kids, (c) full-time work, and (d) fair or poor health. Females have a significantly higher probability of not taking sick leave, as are employees with children. Another significant predictor of denied or suppressed need for leave is poor health status.

\section{[Insert Figure 2 about here]}

Figure 2 plots suppressed leave by the (a) hourly wage, (b) age, (c) number of children in the household, and (d) pain level. Note that, in general, the outcome "suppressed need for sick leave" is a combination of the coverage probability (industry, type and quality of job) as well as the push factors that drive the demand for paid sick leave (health status, family context).

Figure 2a shows that "suppressed need" is particularly prevalent amongst low-income earners who make less than $\$ 20$ per hour. Suppressed need significantly decreases for hourly wages between $\$ 20$ and $\$ 40$, and then further decreases for wages above $\$ 40$ per hour.

Figure $2 \mathrm{~b}$ illustrates that suppressed need peaks at the age of 30 , at a weekly incidence of around $7 \%$. It then smoothly declines until age $63-$ with a $4 \%$ incidence. Note that the presenteeism rate is significantly larger than zero over the entirety of the working age span up to retirement age. 
Figure $2 c$ shows that suppressed need sharply increases when one has between three and four kids in the household. Moreover, the rate also sharply increases between individual pain levels of 4 and 9 on the pain scale of 0 to 10 (Figure $2 d$ ).

Multivariate Regression Results. The final empirical step is to once again use a multivariate regression framework to keep several socio-demographic determinants simultaneously constant and understand how the likelihood of engaging in presenteeism behavior changes when only one factor is varied (Table 1, columns (3) to (6)). Each column represents one regression model with Suppressed Sick Leave ("Presenteeism") as the outcome variable. ${ }^{7}$

The regression results reveal three key factors which determine whether a US employee is at risk of engaging in presenteeism behavior. These risk factors include (i) being a woman, (ii) having children, (iii) being in bad health.

Even in the most saturated model in column (6)-controlling for salary, type of job, industry, number of kids, and health-employed women are still about 50\% (1.1ppt) more likely to suppress their need for sick leave. Each child additionally increases the risk by a significant $13 \%$ (0.3ppt). Explanations for the higher prevalence could be the "double burden" or "time squeeze" hypothesis, which states that the number of working hours and responsibilities have particularly increased for females in the last decades (Leete and Schoor 1994; Costa, 2000; Bratberg et al.

\footnotetext{
${ }^{7}$ Note that the statistical power in these models is reduced since only $2 \%$ of all respondents indicated that they needed but could not or did not take sick leave in the week prior to the interview.
} 
2002). Gender-based sorting into specific types of jobs and workplace discrimination are alternative explanations.

Finally, being in fair or poor health and presenteeism behavior are significantly correlated. Employees in self-reported fair or poor health are almost twice as likely (1.87ppt) - as compared to employees in better health - to report that they would have needed to take sick leave but did not or could not take it in the past week. This finding is confirmed by the significant result for pain. A one unit increase in pain level-on the pain scale from 0 to 10 -is associated with a $0.7 p p t$ higher likelihood of suppressing the need for sick leave, even after controlling for sociodemographics and the type of job. Note again that the direction of causality could go either way: It may be possible that employees in poor health lack access to "good" jobs with paid sick leave coverage, or it could be that the lack of paid sick leave coverage leads to worse health.

\section{Conclusion}

This paper profiles the sick leave landscape in the US-the only industrialized country without universal access to paid sick leave. First, our empirical analysis shows that the overall coverage rate among employees is $55 \%$. Whereas middle-aged full-time employees in finance or public administration have relatively high coverage rates of around 80 or $90 \%$, part-time and lowincome service sector workers with children have significantly lower coverage rates of below $30 \%$.

Second, we estimate that the total demand for paid sick leave to lie at around $10 \%$ among the US workforce in a given week of the working year. About six percent take sick leave, paid or 
unpaid, and two percent find ways to re-arrange their working hours. However, in any given week of the year, an estimated two percent-or about three million-of US employees go to work while sick. These two percent who work sick are primarily women, with kids, low-income, and in bad health. We estimate that the presenteeism rate could be significantly reduced under comprehensive paid sick leave coverage.

\section{Literature}

Ahn, T. and A. Yelowitz (2015): "The short-run impacts of Connecticut's paid sick leave legislation," Applied Economics Letter, 22(15): 1267-1272.

Ben-Ishai, L. (2014): "Access to paid leave: an overlooked aspect of economic \& social inequality," Center for Law and Social Policy (CLASP), http://www.clasp.org/highlights/access-to-paid-leavean-overlooked-aspect-of-economic-social-inequality, retrieved on January 6, 2016.

Blank, P. R., Schwenkglenks, M. M. and T. D. Szucs (2009): "Vaccination coverage rates in eleven European countries during two consecutive influenza seasons," Journal of Infection, 58(6): 446458.

Bureau of Labor Statistics (BLS) (2014): American Time Use Survey User's Guide: Understanding ATUS 2003 to 2013, http://www.bls.gov/tus/atususersguide.pdf, retrieved on April 30, 2015.

Bureau of Labor Statistics (BLS) (2015): Employment, Hours, and Earnings from the Current Employment Statistics Survey (National), http://data.bls.gov/timeseries/CES0000000001, last retrieved May 15, 2015.

Boots, S. W., K. Martinson, and A. Danziger (2009). "Employers' perspectives on San Francisco's paid sick leave policy," The Urban Institute. http://www.urban.org/publications/411868.html, retrieved on April 5, 2012.

Bratberg, E., Dahl, S.-A., Risa, A. E. (2002): “'The Double Burden': Do combinations of career and family obligations increase sickness absence among women?" European Sociological Review, 18(2): 233-249.

Busse, R. and A. Riesberg (2004): Health Care Systems in Transition: Germany (1st edition). WHO Regional Office for Europe on behalf of the European Observatory on Health Systems and Policies. 
Centers for Disease Control and Prevention (2014a): "Final state-level influenza vaccination coverage estimates for the 2010-2011 season," United States, National Immunization Survey and Behavioral Risk Factor Surveillance System, August 2010 through May 2011. CDC. http://www.cdc.gov/flu/fluvaxview/coverage 1011estimates.htm, retrieved on June 19, 2014

Centers for Disease Control and Prevention (2014b): Seasonal Influenza (Flu), CDC. http://www.cdc.gov/flu/about/disease/index.htm, retrieved on September 9, 2014.

Council of Economic Advisors (CEA) (2014): “The economics of paid and unpaid leave," mimeo.

Earn, D. J. D., P. W. Andrews, and B. M. Bolker (2014): “Population-level effects of suppressing fever," Proceedings of the Royal Society B: Biological Sciences, 281(1778).

Gault, B., Hartmann, H., Hegewisch, A., Milli, J., Reichlin, L. (2014): "Paid parental leave in the United States: What the data tell us about access, usage, and economic and health benefits," Institute for Women's Policy Research (IWPR), Report, http://www.iwpr.org/publications/pubs/paid-parental-leave-in-the-united-states-what-thedata-tell-us-about-access-usage-and-economic-and-health-benefits/\#sthash.pxNwsXpz.dpuf, retrieved on May 15, 2015.

Han, W.-J., Ruhm, C., and J. Waldfogel (2009): “Parental leave policies and parents' employment and leave-taking," Journal of Policy Analysis and Management, 28(1): 29-54.

Heymann, J., H. J. Rho, J. Schmitt, and A. Earle (2010): "Ensuring a healthy and productive workforce: Comparing the generosity of paid sick day and sick leave policies in 22 Countries," International Journal of Health Services, 40(1): 1-22.

Leete, L. and Schor, J. B (1994): “Assessing the time-squeeze hypothesis: Hours worked in the United States, 1969-89," Industrial Relations: A Journal of Economy and Society, 33(1): 25-43.

Levin-Epstein, Jodie (2005): "Presenteeism and paid sick days," Center for Law and Social Policy (CLASP), www.clasp.org/resources-and-publications/files/0212.pdf, retrieved January 6, 2015.

Lindemann, A., and K. Miller. 2012. "Paid time off: The elements and prevalence of Consolidated Leave Plans, Institute for Women's Policy Research," http://www.iwpr.org/publications/pubs/paid-time-off-the-elements-and-prevalence-ofconsolidated-leave-plans, retrieved on November 5, 2015.

Lovell, V. (2003): “No time to be sick: Why everyone suffers when workers don't have paid sick leave," Institute for Women's Policy Research. http://www.iwpr.org/publications/pubs/no-timeto-be-sick-why-everyone-suffers-when-workers-don2019t-have-paid-sick-leave, retrieved on September 14, 2015. 
Pichler, S., and N. R. Ziebarth (2015): "The pros and cons of sick pay schemes: Testing for contagious presenteeism and shirking behavior," Upjohn Working Papers 15-239, W.E. Upjohn Institute for Employment Research, https://ideas.repec.org/p/upj/weupjo/15-239.html, retrieved on January 5, 2016.

Public Welfare Foundation (2008): Paid Sick Days: A Basic Labor Standard for the $21^{\text {st }}$ Century, National Opinion Research Center (NORC) at the University of Chicago, prepared by Dr. Tom W. Smith, http://www.norc.org/PDFs/publications/PaidSickDaysReport.pdf, retrieved on January 6, 2016.

Rossin-Slater, M.; Ruhm, C. J., and J. Waldfogel (2013): "The effects of California's paid family leave program on mothers' leave-taking and subsequent labor market outcomes," Journal of Policy Analysis and Management, 32(2): 224-245, 03.

Schliwen, A., Earle, A., Hayes, J., and J. S. Heymann (2011): "The administration and financing of paid sick leave," International Labour Review, 150(1-2): 43-62.

Techniker Krankenkasse (2015): Gesundheitsreport 2015, http://www.tk.de/tk/broschuerenund-mehr/studien-und-auswertungen/gesundheitsreport-2015/718618, retrieved on November 5, 2015.

United States Department of Labor (2015): American Time Use Survey, 2003-2013 [United States]: Arts Activities. ICPSR35530-v1. Ann Arbor, MI: Inter-university Consortium for Political and Social Research [distributor], 2015-01-10. http://doi.org/10.3886/ICPSR35530.v1.

Van Giezen, R. W. 2013. "Paid leave in private industry over the past 20 years," Beyond the Numbers: Pay \& Benefits, 2(18) U.S. Bureau of Labor Statistics, http://www.bls.gov/opub/btn/volume-2/paid-leave-in-private-industry-over-the-past-20-

years.htm, retrieved February 5, 2016.

World Health Organization (2014): Influenza (Seasonal). WHO. http://www.who.int/mediacentre/factsheets/fs211/en, retrievedon September 14, 2014.

Ziebarth, N. R. (2010): "Measurement of health, health inequality, and reporting heterogeneity," Social Science\& Medicine, 71(1): 116-124.

Ziebarth, N. R. (2013): "Long-term absenteeism and moral hazard - Evidence from a natural experiment," Labour Economics, 42: 277-292.

Ziebarth, N. R. and M. Karlsson (2010): "A natural experiment on sick pay cuts, sickness absence, and labor costs," Journal of Public Economics 94(11-12): 1108-1122.

Ziebarth, N. R. and M. Karlsson (2014): "The effects of expanding the generosity of the statutory sickness insurance system," Journal of Applied Econometrics 29(2), 208-230. 


\section{Figures and Tables}

Figure 1: Access to Paid Sick Leave by (a) Hourly Wage, (b) Age, (c) \#Children, (d) Pain

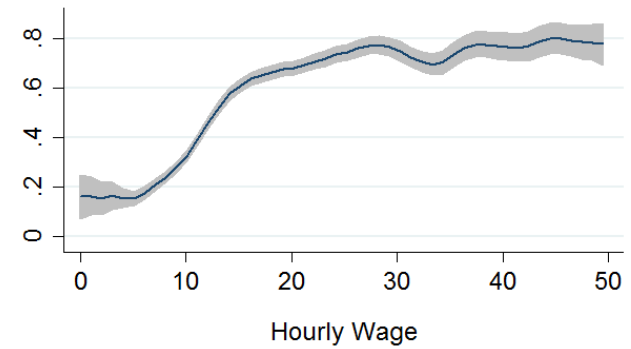

kernel $=$ epanechnikov, degree $=0$, bandwidth $=1.81$, pwidth $=2.72$

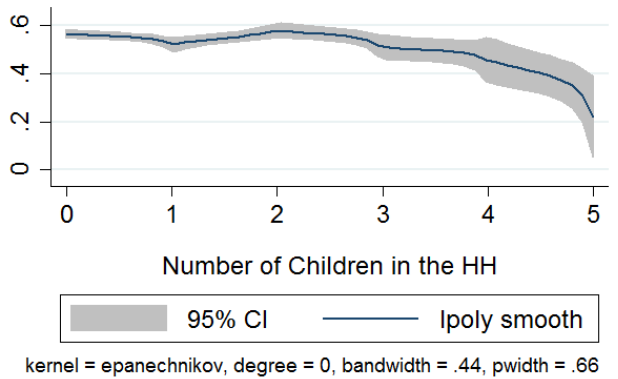

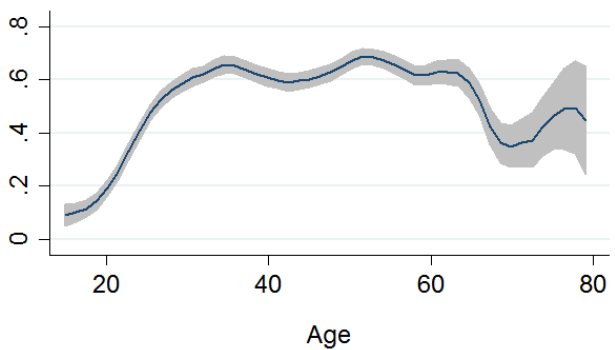

kernel $=$ epanechnikov, degree $=0$, bandwidth $=1.92$, pwidth $=2.88$

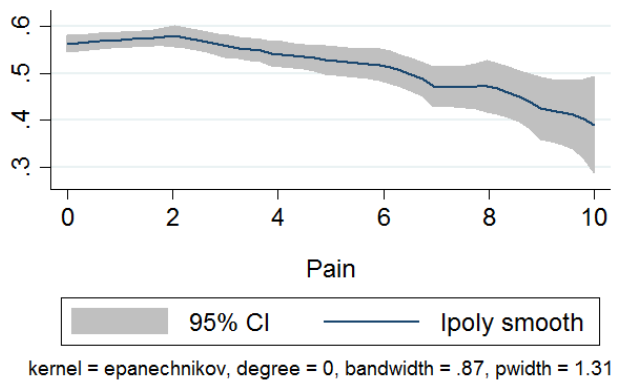

Figure 2: Needed but Didn't Take Sick Leave by (a) Hourly Wage, (b) Age, (c) \#Children, (d) Pain
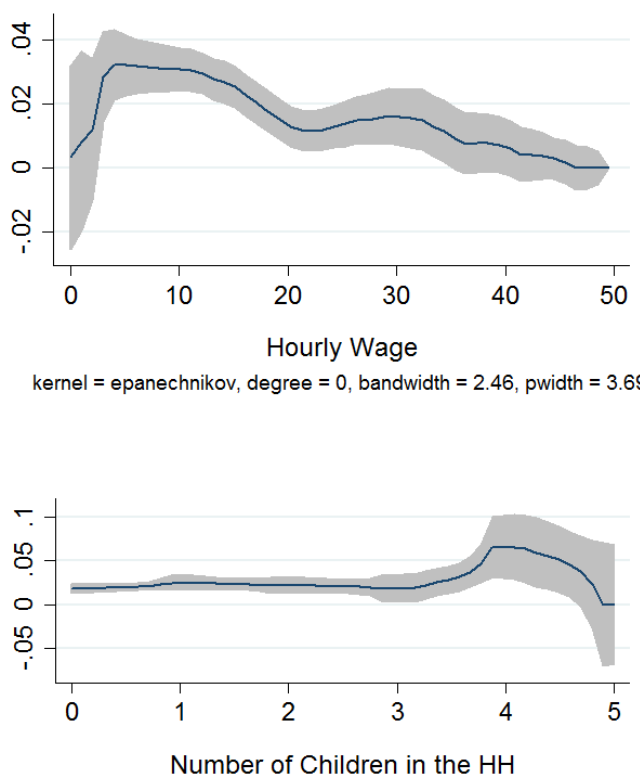

$95 \% \mathrm{Cl}$ Ipoly smooth

kernel $=$ epanechnikov, degree $=0$, bandwidth $=.39$, pwidth $=.58$

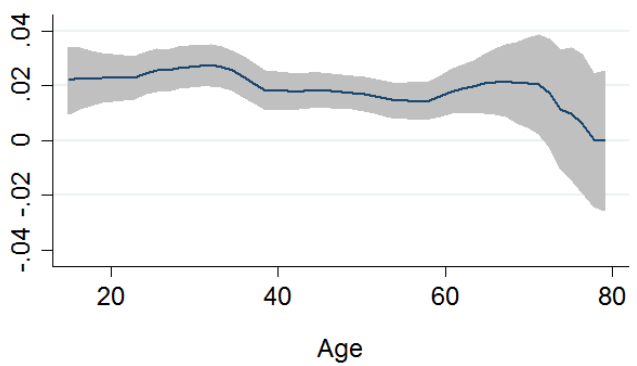

kernel $=$ epanechnikov, degree $=0$, bandwidth $=3.46$, pwidth $=5.19$

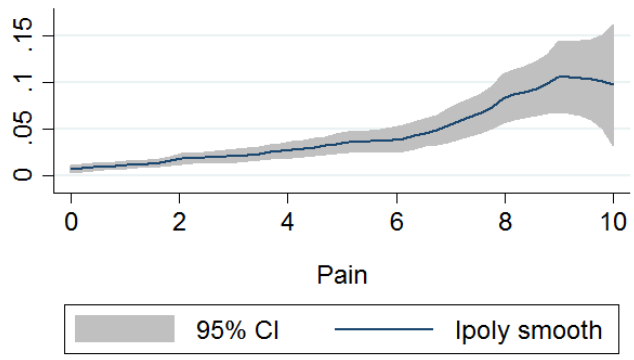

kernel $=$ epanechnikov, degree $=0$, bandwidth $=.89$, pwidth $=1.33$ 
Table 1: Who Has Access to Paid Sick Leave? Who Needed but Did Not Take Sick Leave?

\begin{tabular}{|c|c|c|c|c|c|c|}
\hline & \multicolumn{3}{|c|}{ Access to Paid Sick Leave } & \multicolumn{3}{|c|}{$\begin{array}{l}\text { Suppressed Sick Leave } \\
\text { (“Presenteeism”) }\end{array}$} \\
\hline & (1) & (2) & (3) & (4) & (5) & (6) \\
\hline Age & $\begin{array}{c}0.0528 * * * \\
(0.0024)\end{array}$ & $\begin{array}{c}0.0218^{* * *} \\
(0.0026)\end{array}$ & $\begin{array}{c}0.0227^{* * *} \\
(0.0026)\end{array}$ & $\begin{array}{c}-0.0002 \\
(0.0007)\end{array}$ & $\begin{array}{l}-0.0002 \\
(0.0008)\end{array}$ & $\begin{array}{l}-0.0007 \\
(0.0008)\end{array}$ \\
\hline Age2 & $\begin{array}{c}-0.0006^{* * *} \\
(0.0000)\end{array}$ & $\begin{array}{c}-0.0002^{* * *} \\
(0.0000)\end{array}$ & $\begin{array}{c}-0.0002^{* * *} \\
(0.0000)\end{array}$ & $\begin{array}{l}-0.0000 \\
(0.0000)\end{array}$ & $\begin{array}{c}0.0000 \\
(0.0000)\end{array}$ & $\begin{array}{c}0.0000 \\
(0.0000)\end{array}$ \\
\hline Female & $\begin{array}{l}-0.0161 \\
(0.0119)\end{array}$ & $\begin{array}{l}-0.0086 \\
(0.0121)\end{array}$ & $\begin{array}{l}-0.0045 \\
(0.0121)\end{array}$ & $\begin{array}{c}0.0160 * * * \\
(0.0036)\end{array}$ & $\begin{array}{c}0.0145^{* * *} \\
(0.0039)\end{array}$ & $\begin{array}{c}0.0112 * * * \\
(0.0039)\end{array}$ \\
\hline Number Children HH & $\begin{array}{c}-0.0175^{* * *} \\
(0.0057)\end{array}$ & $\begin{array}{l}-0.0030 \\
(0.0053)\end{array}$ & $\begin{array}{l}-0.0023 \\
(0.0052)\end{array}$ & $\begin{array}{c}0.0027 \\
(0.0017)\end{array}$ & $\begin{array}{l}0.0028^{*} \\
(0.0017)\end{array}$ & $\begin{array}{l}0.0028 * \\
(0.0017)\end{array}$ \\
\hline Hourly Wage & & $\begin{array}{c}0.0295^{* * *} \\
(0.0089)\end{array}$ & $\begin{array}{c}0.0273^{* * *} \\
(0.0089)\end{array}$ & & $\begin{array}{l}-0.0043 \\
(0.0029)\end{array}$ & $\begin{array}{l}-0.0036 \\
(0.0029)\end{array}$ \\
\hline Hourly Wage2 & & $\begin{array}{c}-0.0014^{* * *} \\
(0.0004)\end{array}$ & $\begin{array}{c}-0.0013^{* * *} \\
(0.0004)\end{array}$ & & $\begin{array}{c}0.0002 \\
(0.0001)\end{array}$ & $\begin{array}{c}0.0001 \\
(0.0001)\end{array}$ \\
\hline Fulltime & & $\begin{array}{c}0.3468^{* * *} \\
(0.0157)\end{array}$ & $\begin{array}{c}0.3447^{* * *} \\
(0.0156)\end{array}$ & & $\begin{array}{l}-0.0017 \\
(0.0051)\end{array}$ & $\begin{array}{c}0.0002 \\
(0.0050)\end{array}$ \\
\hline In School or College & & $\begin{array}{c}-0.0084 \\
(0.0210)\end{array}$ & $\begin{array}{l}-0.0172 \\
(0.0209)\end{array}$ & & $\begin{array}{c}-0.0128 * \\
(0.0068)\end{array}$ & $\begin{array}{l}-0.0103 \\
(0.0067)\end{array}$ \\
\hline Mining & & $\begin{array}{c}0.0798 \\
(0.0871)\end{array}$ & $\begin{array}{c}0.0529 \\
(0.0868)\end{array}$ & & $\begin{array}{c}0.0114 \\
(0.0282)\end{array}$ & $\begin{array}{c}0.0128 \\
(0.0280)\end{array}$ \\
\hline Construction & & $\begin{array}{c}0.0148 \\
(0.0635)\end{array}$ & $\begin{array}{c}-0.0034 \\
(0.0633)\end{array}$ & & $\begin{array}{c}0.0046 \\
(0.0206)\end{array}$ & $\begin{array}{c}0.0101 \\
(0.0204)\end{array}$ \\
\hline Manufacturing & & $\begin{array}{c}0.2182^{* * *} \\
(0.0618)\end{array}$ & $\begin{array}{c}0.1963 * * * \\
(0.0616)\end{array}$ & & $\begin{array}{c}0.0132 \\
(0.0200)\end{array}$ & $\begin{array}{c}0.0205 \\
(0.0198)\end{array}$ \\
\hline Wholesale \& retail trade & & $\begin{array}{c}0.2027^{* * *} \\
(0.0612)\end{array}$ & $\begin{array}{c}0.1799 * * * \\
(0.0610)\end{array}$ & & $\begin{array}{c}0.0130 \\
(0.0198)\end{array}$ & $\begin{array}{c}0.0199 \\
(0.0197)\end{array}$ \\
\hline $\begin{array}{l}\text { Transportation \& } \\
\text { utilities }\end{array}$ & & $\begin{array}{c}0.3118^{* * *} \\
(0.0639)\end{array}$ & $\begin{array}{c}0.2894 * * * \\
(0.0637)\end{array}$ & & $\begin{array}{c}0.0041 \\
(0.0207)\end{array}$ & $\begin{array}{c}0.0105 \\
(0.0205)\end{array}$ \\
\hline Information & & $\begin{array}{c}0.2202^{* * *} \\
(0.0688)\end{array}$ & $\begin{array}{c}0.1879 * * * \\
(0.0686)\end{array}$ & & $\begin{array}{c}0.0199 \\
(0.0223)\end{array}$ & $\begin{array}{c}0.0304 \\
(0.0221)\end{array}$ \\
\hline Financial activities & & $\begin{array}{c}0.4175^{* * *} \\
(0.0638)\end{array}$ & $\begin{array}{c}0.3838 * * * \\
(0.0636)\end{array}$ & & $\begin{array}{c}0.0195 \\
(0.0206)\end{array}$ & $\begin{array}{c}0.0314 \\
(0.0205)\end{array}$ \\
\hline $\begin{array}{l}\text { Prof. \& business } \\
\text { services }\end{array}$ & & $\begin{array}{c}0.2479 * * * \\
(0.0617)\end{array}$ & $\begin{array}{c}0.2162 * * * \\
(0.0615)\end{array}$ & & $\begin{array}{c}0.0036 \\
(0.0200)\end{array}$ & $\begin{array}{c}0.0148 \\
(0.0198)\end{array}$ \\
\hline Edu. \& health & & $\begin{array}{c}0.3201^{* * *} \\
(0.0606)\end{array}$ & $\begin{array}{c}0.2888 * * * \\
(0.0605)\end{array}$ & & $\begin{array}{c}0.0103 \\
(0.0196)\end{array}$ & $\begin{array}{c}0.0203 \\
(0.0195)\end{array}$ \\
\hline Leisure \& hospitality & & $\begin{array}{c}0.0545 \\
(0.0623)\end{array}$ & $\begin{array}{c}0.0362 \\
(0.0620)\end{array}$ & & $\begin{array}{c}0.0183 \\
(0.0201)\end{array}$ & $\begin{array}{c}0.0221 \\
(0.0200)\end{array}$ \\
\hline Other services & & $\begin{array}{c}0.1071 \\
(0.0660)\end{array}$ & $\begin{array}{c}0.0818 \\
(0.0658)\end{array}$ & & $\begin{array}{c}0.0137 \\
(0.0213)\end{array}$ & $\begin{array}{c}0.0187 \\
(0.0212)\end{array}$ \\
\hline Public administration & & $0.4977 * * *$ & $0.4645 * * *$ & & 0.0011 & 0.0127 \\
\hline
\end{tabular}


(0.0642)

Fair or poor health

Good health

Very good health

Pain (scale 0-10)

Constant

$-0.5547 * * * \quad-0.4424 * * *$

(0.0526)

(0.0800)

6,354

0.0887

Observations

6,354

R-squared

0.2325

(0.0641)

$-0.1122^{* * *}$

(0.0245)

$-0.0710 * * *$

(0.0156)

0.0078

(0.0140)

$-0.0039$

(0.0025)
(0.0208)

(0.0206)

$0.0187^{* *}$

(0.0079)

$0.0092^{*}$

(0.0050)

$-0.0018$

(0.0045)

$0.0071^{* * *}$

(0.0008)

0.0011

(0.0257)

0.0127

(0.0259)

(0.0799)

0.0169

(0.0157)

\section{6,354}

6,354

6,354

6,354

0.0058

0.0082

0.0268

Source: ATUS 2011, Leave Module, own illustration. ${ }^{*} p<0.1,{ }^{* *} p<0.05,{ }^{* * *} p<0.01$; standard errors are in parentheses. Each column stands for one Linear Probability Model. The results are robust to estimating probit models and calculating marginal effects. All regression models are weighted using the ATUS provided leave module weights. The binary dependent variable in the first three columns indicates whether interviewed employees have access to paid sick leave. The binary dependent variable in the last three columns indicates whether interviewed employees needed to take leave but did not do it in the week prior to the interview. All regressions include controls for the calendar month of the interview. See the Appendix for more details on the covariates. The findings are robust to excluding those 114 respondents with an hourly wage of more than $\$ 200$.

Table 2: Among Employees Who Needed but Didn't Take Sick Leave, Reasons for not Taking:

\begin{tabular}{|c|c|}
\hline & Percent \\
\hline \multicolumn{2}{|l|}{ Lack of Comprehensive Coverage } \\
\hline Could not Afford Loss in Income & 27.20 \\
\hline Wanted To Save Leave & 6.78 \\
\hline Leave Was Denied & 4.59 \\
\hline \multirow[t]{2}{*}{ Did Not Have Enough Leave } & 1.70 \\
\hline & 40.27 \\
\hline \multicolumn{2}{|l|}{ Job Consequences and Other } \\
\hline Fear of Job Loss or Other Negative Outcome & 11.01 \\
\hline Too Much Work & 20.36 \\
\hline Other & 28.37 \\
\hline Total & 100 \\
\hline $\begin{array}{l}\text { Source: ATUS 2011, Leave Module, own illustration. } \\
\text { leave module weights are applied. }\end{array}$ & provided \\
\hline
\end{tabular}




\section{Appendix}

Figure A1: Access to Paid Sick Leave by (a) Gender, (b) Children, (c) Full-time work, (d) Health
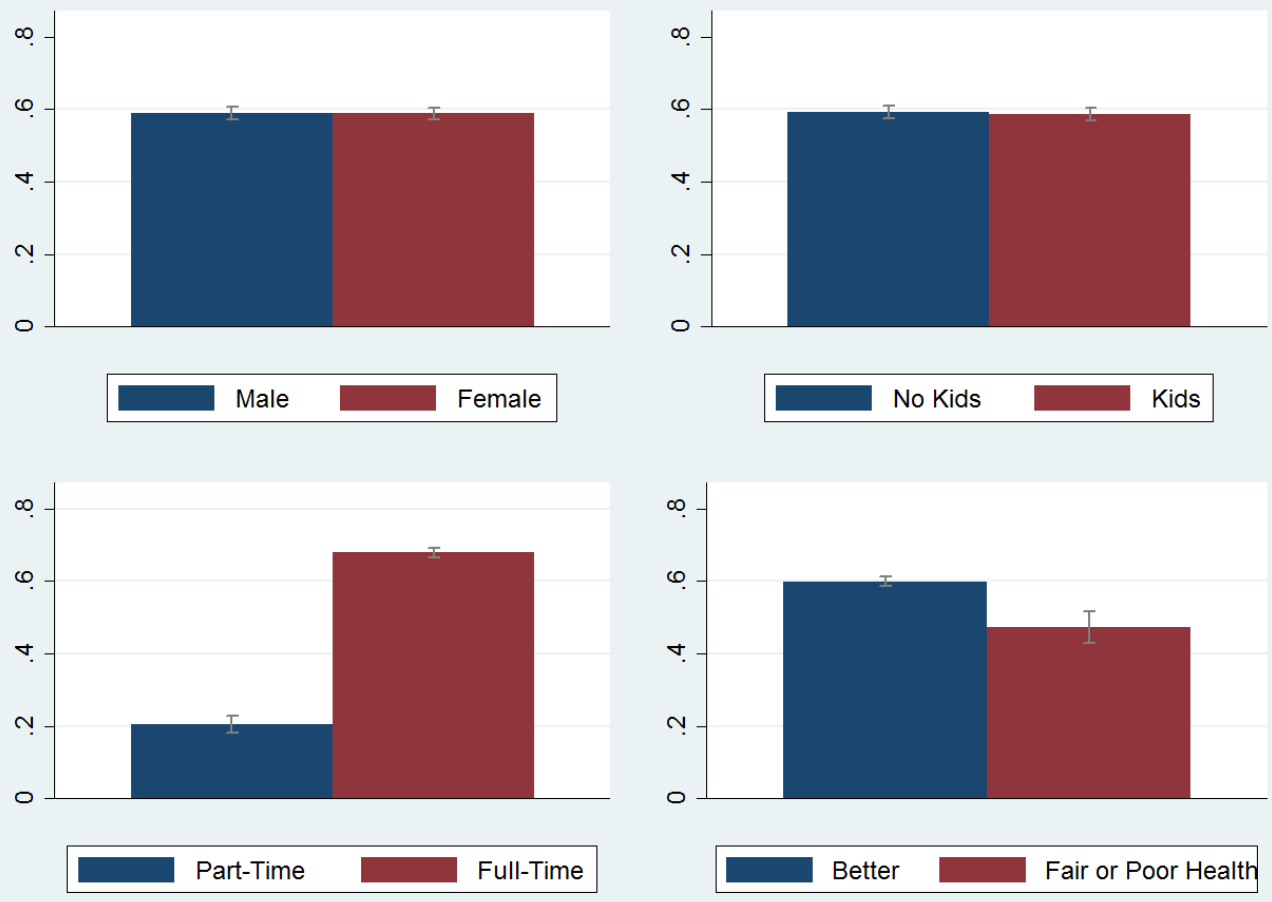

Figure A2: Needed but Didn't Take Leave by (a) Gender, (b) Children, (c) Full-time, (d) Health
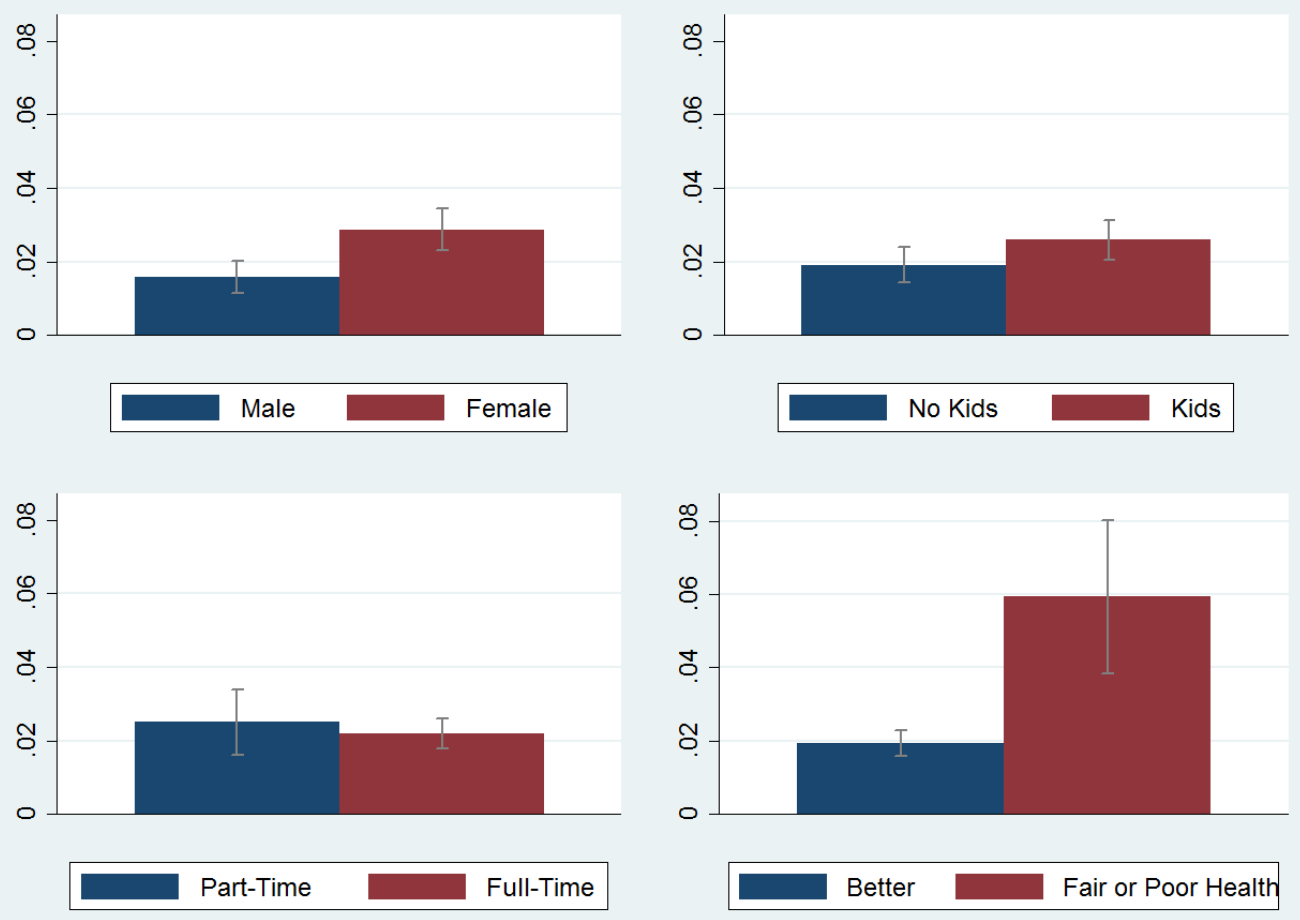
Table A1: Descriptive Statistics

\begin{tabular}{|c|c|c|c|c|c|}
\hline & Obs & Mean & Std. Dev. & Min & Max \\
\hline \multicolumn{6}{|l|}{ Access to Paid or Unpaid Leave } \\
\hline Access to Paid Leave & 6354 & 0.6106 & 0.4877 & 0 & 1 \\
\hline Could Take Upaid Leave & 6354 & 0.7743 & 0.4181 & 0 & 1 \\
\hline No Paid or Unpaid Leave Possible & 6354 & 0.0851 & 0.2790 & 0 & 1 \\
\hline Access to Paid Sick Leave & 6354 & 0.5519 & 0.4973 & 0 & 1 \\
\hline Access to Paid Leave for Sick Relative & 6354 & 0.4408 & 0.4965 & 0 & 1 \\
\hline Access to Paid Leave for Child Care & 6354 & 0.4035 & 0.4906 & 0 & 1 \\
\hline Access to Paid Leave for Elder Care & 6354 & 0.2672 & 0.4426 & 0 & 1 \\
\hline Access to Paid Leave for Child Birth & 6354 & 0.4035 & 0.4906 & 0 & 1 \\
\hline \multicolumn{6}{|l|}{ Utilization of Paid and Unpaid Leave Last Week } \\
\hline Sick and Took Sick Leave i & 6354 & 0.0480 & 0.2137 & 0 & 1 \\
\hline Relative Sick and Took Sick Leave & 6354 & 0.0158 & 0.1246 & 0 & 1 \\
\hline Rescheduled Work Instead of Leave & 6354 & 0.0471 & 0.2119 & 0 & 1 \\
\hline Needed but Didn't Take or Get it & 6354 & 0.0449 & 0.2070 & 0 & 1 \\
\hline \multicolumn{6}{|l|}{ Type of Work } \\
\hline Hourly Gross Wage & 6354 & 41.45 & 173.39 & 0.025 & 2885 \\
\hline Full-time job & 6354 & 0.8111 & 0.3914 & 0 & 1 \\
\hline Part-time job & 6354 & 0.1889 & 0.3914 & 0 & 1 \\
\hline Industry & 6354 & 7.9467 & 3.0283 & 1 & 13 \\
\hline Agriculture, forestry, fishing, and hunting & 6354 & 0.0086 & 0.0922 & 0 & 1 \\
\hline Mining & 6354 & 0.0071 & 0.0839 & 0 & 1 \\
\hline Construction & 6354 & 0.0466 & 0.2108 & 0 & 1 \\
\hline Manufacturing & 6354 & 0.1081 & 0.3106 & 0 & 1 \\
\hline Wholesale and retail trade & 6354 & 0.1254 & 0.3312 & 0 & 1 \\
\hline Transportation and utilities & 6354 & 0.0540 & 0.2260 & 0 & 1 \\
\hline Information & 6354 & 0.0242 & 0.1538 & 0 & 1 \\
\hline Financial activities & 6354 & 0.0626 & 0.2423 & 0 & 1 \\
\hline Professional and business services & 6354 & 0.1117 & 0.3151 & 0 & 1 \\
\hline Educational and health services & 6354 & 0.2795 & 0.4488 & 0 & 1 \\
\hline Leisure and hospitality & 6354 & 0.0795 & 0.2705 & 0 & 1 \\
\hline Other services & 6354 & 0.0354 & 0.1848 & 0 & 1 \\
\hline Public administration & 6354 & 0.0582 & 0.2342 & 0 & 1 \\
\hline \multicolumn{6}{|l|}{ Socio-demographics } \\
\hline Age & 6354 & 40.63 & 13.98 & 15 & 85 \\
\hline Age2 & 6354 & 1847 & 1190 & 225 & 7225 \\
\hline Female & 6354 & 0.4762 & 0.4995 & 0 & 1 \\
\hline Number of Children in $\mathrm{HH}$ & 6354 & 0.7835 & 1.0989 & 0 & 9 \\
\hline Age youngest child & 3209 & 7.5333 & 5.4533 & 0 & 17 \\
\hline Enrolled in School or College & 6354 & 0.1061 & 0.3080 & 0 & 1 \\
\hline Fair or poor health & 6354 & 0.0733 & 0.2607 & 0 & 1 \\
\hline Good health & 6354 & 0.2765 & 0.4473 & 0 & 1 \\
\hline Very good health & 6354 & 0.3821 & 0.4859 & 0 & 1 \\
\hline Excellent health & 6354 & 0.2681 & 0.4430 & 0 & 1 \\
\hline Pain & 6354 & 2.0508 & 2.3860 & 0 & 10 \\
\hline
\end{tabular}


Table A2: Share of American Employees with Access to Paid and Unpaid Leave

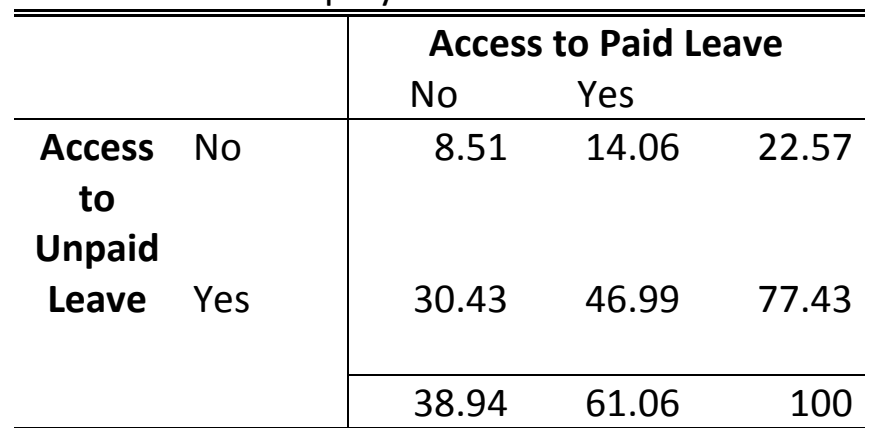

Source: ATUS 2011, Leave Module, own illustration.

The ATUS provided leave module weights are applied. 
Table A3: Access to Paid Leave and Sick Leave by Industries

\begin{tabular}{|c|c|c|}
\hline Variable & Mean & Std. Dev. \\
\hline \multicolumn{3}{|c|}{ Agriculture, forestry, fishing, and hunting } \\
\hline Paid Leave & 0.3568 & 0.4841 \\
\hline Paid Sick Leave & 0.2931 & 0.4600 \\
\hline \multicolumn{3}{|l|}{ Mining } \\
\hline Paid Leave & 0.5522 & 0.5029 \\
\hline Paid Sick Leave & 0.4518 & 0.5033 \\
\hline \multicolumn{3}{|l|}{ Construction } \\
\hline Paid Leave & 0.4138 & 0.4933 \\
\hline Paid Sick Leave & 0.3446 & 0.4760 \\
\hline \multicolumn{3}{|l|}{ Manufacturing } \\
\hline Paid Leave & 0.7450 & 0.4362 \\
\hline Paid Sick Leave & 0.6069 & 0.4888 \\
\hline \multicolumn{3}{|l|}{ Wholesale and retail trade } \\
\hline Paid Leave & 0.5602 & 0.4967 \\
\hline Paid Sick Leave & 0.4749 & 0.4997 \\
\hline \multicolumn{3}{|l|}{ Transportation and utilities } \\
\hline Paid Leave & 0.7347 & 0.4421 \\
\hline Paid Sick Leave & 0.6913 & 0.4626 \\
\hline \multicolumn{3}{|l|}{ Information } \\
\hline Paid Leave & 0.6309 & 0.4841 \\
\hline Paid Sick Leave & 0.5676 & 0.4970 \\
\hline \multicolumn{3}{|l|}{ Financial activities } \\
\hline Paid Leave & 0.8218 & 0.3832 \\
\hline Paid Sick Leave & 0.7806 & 0.4144 \\
\hline \multicolumn{3}{|c|}{ Professional and business services } \\
\hline Paid Leave & 0.5992 & 0.4904 \\
\hline Paid Sick Leave & 0.5682 & 0.4957 \\
\hline \multicolumn{3}{|l|}{ Educational and health services } \\
\hline Paid Leave & 0.6654 & 0.4720 \\
\hline Paid Sick Leave & 0.6342 & 0.4818 \\
\hline \multicolumn{3}{|l|}{ Leisure and hospitality } \\
\hline Paid Leave & 0.2559 & 0.4368 \\
\hline Paid Sick Leave & 0.1857 & 0.3893 \\
\hline \multicolumn{3}{|l|}{ Other services } \\
\hline Paid Leave & 0.4340 & 0.4967 \\
\hline Paid Sick Leave & 0.3593 & 0.4809 \\
\hline \multicolumn{3}{|l|}{ Public administration } \\
\hline $\begin{array}{l}\text { Paid Leave } \\
\end{array}$ & 0.8931 & 0.3095 \\
\hline Paid Sick Leave & 0.8891 & 0.3144 \\
\hline
\end{tabular}

Source: ATUS 2011, Leave Module, own illustration. The ATUS provided leave module weights are applied. 